\title{
Integrative analysis of dietary water footprint and dietary quality - Towards the practical application of sustainable nutrition
}

\author{
O. Tompa ${ }^{1 *}$ (1), O. Kanalas ${ }^{1}$, A. Kiss ${ }^{2}$, S. Soós ${ }^{2}$ and Z. Lakner ${ }^{1}$
}

\footnotetext{
${ }^{1}$ Department of Food Chain Management, Faculty of Economics and Social Sciences, Hungarian University of Agriculture and Life Sciences, Práter K u. 1., H-2100, Gödöllő, Hungary

${ }^{2}$ Faculty of Education and Psychology, Eötvös Loránd University, Kazinczy street 23-27., H-1075, Budapest, Hungary
}

\section{ORIGINAL RESEARCH PAPER}

Received: March 25, 2021 • Accepted: July 28, 2021

Published online: October 1, 2021

(c) 2021 The Author(s)

\section{ABSTRACT}

The contribution of food production to the environmental burden is considerable, therefore, numerous countries have been trying to create a sustainable food supply chain to ensure food and nutrition security. The scope of this study was to analyse the association between water footprint and healthiness based on dietary records. Furthermore, it was aimed to create a classification of integrative dietary indicators of sustainable nutrition. With these methodological aims, the dietary records of 25 healthy adults were assessed. The dietary quality scores and dietary water footprint were calculated and Spearman's rank correlation was tested between them. The indicator nutrients were classified based on their advantageous or disadvantageous health impact and association with water footprint. There was a significant positive correlation between the meat consumption and water footprint, while significant negative correlations were found between the dietary quality score and water footprint and dietary quality score and meat consumption $(P<0.05)$. Protein, energy, sodium, and saturated fatty acids as integrated indicator nutrients could be identified for both dietary quality and water footprint. The improvement in dietary quality could simultaneously decrease the dietary water footprint. The integration of environmental impact into the analysis of diets could be the future direction in the counseling practice of nutritionists.

\footnotetext{
*Corresponding author. E-mail: orsolya.tompa@olympian.org
} 


\section{KEYWORDS}

sustainable nutrition, dietary quality, water footprint

\section{INTRODUCTION}

The nutritional pattern affects not only human health but the environment as well, however, the size of its effect considerably differs depending on the type of diet. Agriculture and livestock farming put a great burden on the environment - especially the production of animal based foods - by pressures such as greenhouse gas emission (GHGE), land and water use, and pollution among others (Fischer and Garnett, 2016; Vanham et al., 2019). In order to decrease this environmental burden, shifting the population nutrition is thought to be a possible direction, therefore, several countries have involved sustainability - thus environmental consideration - into their official food-based dietary guidelines (Fischer and Garnett, 2016). According to the review of Harris et al. (2020), the difference in the dietary WFP of different dietary scenarios could be up to $30 \%$ that is especially important considering that food production contributes to $70 \%$ of the total anthropogenic water footprint and is the major source of water pollution (Fischer and Garnett, 2016). That is one of the reasons why research has put focus on this issue recently (Tompa et al., 2020b; Harris et al., 2020). Noncommunicable diseases (NCDs) are responsible for the $2 / 3^{\text {rds }}$ of total death numbers in Hungary. According to the database of the Global Burden of Disease (GBD), the dietary factors among lifestyle risk factors are the major contributors to the development of NCDs (Institute for Health Metrics and Evaluation (IHME), 2019). Thus, the measurement of the adequacy and healthiness of nutrition is particularly important in order to optimise diets to prevent NCDs. In the field of sustainable nutrition (SN), it is often carried out by describing it with a simple and complex score value (dietary quality scores (DQSs)). It is also a reasonable measurement since SN is characterised by numerous metrics and DQSs can make it easier to understand the complex nature of it. The purpose of DQSs is to classify foods, meals, and diets as advantageous or disadvantageous in the aspect of health. In the recent period, the application of DQSs in the field of SN has become a well-accepted method in the integrated analysis of environmental impact and healthiness of nutrition, however, the application of them still holds some challenges due to the complex nature of metrics (Hallström et al., 2018).

\section{MATERIALS AND METHODS}

The purpose of this study was to analyse the association between dietary water footprint and dietary quality (i.e. healthiness). Furthermore, it was aimed to classify dietary indicators (i.e. nutrients) based on methods published in the international scientific literature (van Dooren et al., 2017; Hallström et al., 2018), while considering the specific Hungarian aspects. These methods could be applicable in the analysis of diets, so they could bring the environmental considerations into the counseling practice of nutritionists as well as serve as an initial step to further research in the field of sustainable nutrition focused on the Hungarian population. 
Twenty-five healthy and adult (18+ years old) volunteers were recruited by an online questionnaire from $08 / 05 / 2019$ to $01 / 16 / 2020$, they could participate anonymously and by accepting GDPR consent. The group of this study included 7 male and 18 female participants, their average age was 28 and they also self-reported their diet: 19 stated not to follow any particular diet and 6 kept plant-based diet. At the time of data collection, 11 individual held college or university degree, while 14 had high school degree; 24 of them lived in the capital or other cities and 1 in a village.

\subsection{Determination of dietary quality scores}

To measure the healthiness of the participants' nutrition, their 3-day dietary records were validated and evaluated with the NutriComp DietCAD (NutriComp Bt., Budapest) diet analysis software that is specific for the characteristics of Hungarian nutrition. By making this analysis, the energy, nutrients, and total meat intake values were determined in the dimension of amount/day/capita averaged for the 3 days. The estimated intake values to calculate DQSs were further processed. Among several methods to calculate DQSs, algorithms that are based on the ratio of nutrient intake values and dietary recommended intake values (RDIs) were applied. To categorise nutrients as qualifying (i.e. advantageous) or dis-qualifying (i.e. disadvantageous) in the aspect of health, the classifications were based on the review of Hallström et al. (2018), as these nutrients were considered as indicators for good or bad dietary quality as applied by several international studies (Hallström et al., 2018). The problematic definition of nutrients as advantageous or disadvantageous can be resolved by considering their population intake level and the health risks or benefits related to this intake level. The RDI components of algorithms were based on the published recommendations of the Hungarian Diet and Nutritional Status Survey for healthy adults (Nagy et al., 2017; Sarkadi Nagy et al., 2017; Schreiberné Molnár et al., 2017). The nutrients classified as advantageous were the followings: total protein ( $\mathrm{g}$ and energy intake share in \%), dietary fibres (g), vitamin $\mathrm{C}(\mathrm{mg})$, calcium (mg), iron (mg), all in the dimension of amount/day/capita. The RDI of protein as nutrient that contributes to energy intake can be described by a range, so the algorithm results in optimal values between the minimum and maximum limit of the range and starts to decrease above and below it. The algorithm of protein (energy intake share in \%) in the DQS:

$$
p(x)=\left\{\begin{array}{c}
\frac{2 x}{x_{r e f_{\min }}+x_{r e f_{\max }}}+0.2, \text { if } x<x_{r e f_{\min }} \\
1, \text { if } x_{\min } \leq x \leq x_{r e f_{\max }} \\
-\frac{2 x}{x_{r e f_{\min }}+x_{r e f_{\max }}}+2.2, \text { if } x>x_{r e f_{\max }}
\end{array}\right.
$$

where: $p$ is the subscore referring to protein, $x$ is the amount of protein in the diet, $x_{r e} f_{\min }$ minimum limit of the RDI range, and $x_{r e f_{\max }}$ maximum limit of the RDI range. In the case of other advantageous nutrients, the algorithm increases up to $150 \%$ of the RDI but not above, since the intake of excessive doses cannot be considered as advantageous and may cover the low intake of others. The algorithm of advantageous nutrients in the other DQS: 


$$
N_{A}(x)=\left\{\begin{array}{c}
\frac{x}{x_{r e f}}, \text { if } x \leq x_{r e f} * 1.5 \\
1.5, \text { if } x>x_{\text {ref }} * 1.5
\end{array}\right.
$$

where: $\mathrm{N}_{\mathrm{A}}$ is the subscore refers to advantageous nutrients, $x$ is the amount of advantageous nutrient in the diet, and $x_{\text {ref }}$ RDI of the advantageous nutrient. The nutrients classified as disadvantageous were the followings: energy (kcal), sodium (mg), saturated fatty acids ( $\mathrm{g}$ and energy intake share in \%), and added sugars ( $\mathrm{g}$ and energy intake share in \%), all in the dimension of amount/day/capita. The determination of the ideal value of energy intake was more sophisticated, since it was necessary to consider the participants' physical activity level beside their individual parameters: gender, age, body weight and height. The physical activity level coefficients were calculated based on the published paper by the European Food Safety Authority (EFSA, 2017), for which the data were acquired from the initial online questionnaire filled out by the participants. The algorithm of disadvantageous nutrients in the DQS was:

$$
N_{D A}(x)=1-\left(\frac{x}{x_{r e f}}-1\right)
$$

where: $\mathrm{N}_{\mathrm{DA}}$ is the subscore refers to disadvantageous nutrients, $x$ is the amount of disadvantageous nutrient in the diet, and $x_{r e f}$ RDI of the disadvantageous nutrient. Furthermore, the total meat intake as a sustainable dietary quality indicator was also assessed, since the animal-based foods, especially meats, are usually the largest contributors to the dietary WFP (Harris et al., 2020). Besides, according to the database of the GBD, the high processed and red meat intakes can be identified as individual dietary risk factors for the development of NCDs (IHME, 2019).

\subsection{Estimation of dietary WFP}

WFP is a term that refers to the volume and way of application of used water resources for the production of a certain product; thus, it is often called as "virtual water". There are three types of WFP classified: green, blue, and grey. Green water is from precipitation and stored in the soil, wherefrom plants absorb it; it is especially relevant for agricultural products. Blue water is from the surface or groundwater stores and used for irrigation and industrial and domestic applications. Grey water is the amount of water used to dilute the pollution of used water to meet specific water quality standards (Barilla Center for Food and Nutrition, 2015). In this study, in the accordance with the methods applied in the field of SN, the total WFP values (including green, blue, and grey) were calculated by considering the total WFP values of each food categories as products (Hoekstra and Mekonnen, 2012; Vanham et al., 2013; Harris et al., 2020; Vanham, 2020). To estimate the dietary WFP of diets, the data on food intake from the dietary records were compiled with water footprint values of food categories. The WFP values were acquired from the database of Barilla Center for Food and Nutrition, in which hundreds of published data and databases are systemised and averaged at the level of food categories (Barilla Center for Food and Nutrition, 2015). As the result of this analysis, the dietary WFP of the participants in the dimension of L/day/capita could be estimated. 
Table 1. Association of nutrients and water footprint of diets $(n=25)$. Spearman's rank correlation

\begin{tabular}{lccc}
\hline Type of nutrient & \multicolumn{3}{c}{ Type and direction of the correlation } \\
\hline $\begin{array}{l}\text { (1) Advantageous in the } \\
\text { aspect of health }\end{array}$ & - & protein $^{* * *}$ & $\begin{array}{c}\text { dietary fibres, iron, } \\
\text { vitamin C, calcium, } \\
\text { added sugars }\end{array}$ \\
$\begin{array}{l}\text { (2) Disadvantageous in the } \\
\text { aspect of health }\end{array}$ & $\begin{array}{c}\text { (a) significant }(-) \\
\text { correlation with water } \\
\text { footprint }\end{array}$ & $\begin{array}{c}\text { (b) significant }(+) \\
\text { correlation with water } \\
\text { footprint }\end{array}$ & $\begin{array}{c}\text { (c) no significant } \\
\text { correlation }\end{array}$ \\
\end{tabular}

Significance levels: $P<0.001^{* * *}, P<0.01^{* *}, P<0.05^{*}$

\subsection{The integrative analysis of dietary quality and WFP}

From the several methods to integrate the aspects of dietary quality and environmental impact (Hallström et al., 2018), the following approach was selected: (1) At first, the dietary quality as scores values, dietary WFP values (L/day/capita), and total meat intake (gram/day/capita), which were considered as variables, were separately calculated,. (2) Then, correlation analyses were carried out between these variables. Based on the type of scales and non-normal distribution of variables (Shapiro-Wilk test, $P<0.05$ ), Spearman's rank correlation was applied at the significance level of $P<0.05$. Excel 2016 was used for the calculation of algorithms and Jamovi statistical analysis software for the correlation analyses (Jamovi, 2020; R Core Team, 2019). Our sample size $(n=25)$ was appropriate to determine the significance values of Spearman's rank correlation results according to an assessment of correlative statistical test (May and Looney, 2020). The sample could not be regarded as representative; however, it was suitable for our methodological aims. In the studies published in the field of SN, the search for indicator nutrients integrating environmental impact and dietary quality is a common aim (Hendrie et al., 2016, Saarinen et al., 2017; van Dooren et al., 2017). Therefore, a classification on the principles of the followings was also created: (I.) Type of the nutrient: (1) advantageous in the aspect of health, (2) disadvantageous in the aspect of health (Hallström et al., 2018) and (II.) Type of correlation between the nutrient and WFP: (a) significant and positive, (b) significant and negative, (c) no significant correlation (Table 1).

\section{RESULTS AND DISCUSSION}

The associations between the DQS, total meat intake, and WFP of the 25 participants were analysed. There was a positive significant correlation between total meat intake and WFP (Fig. 1A), while a negative significant correlation between DQS and WFP (Fig. 1C) as well as total meat intake and DQS (Fig. 1B). The mean WFP volume of the analysed dietary records was $2,629 \mathrm{~L} /$ day/capita $( \pm 879)$ that is lower than the results $(4,053 \mathrm{~L} /$ day/capita $)$ of the only analysis focused on this region of Europe calculating with total WFP values (Vanham et al., 2013). This difference can be explained by the fact that they estimated the nationally typical food intake based on databases, while this study analysed dietary records, an observation already pointed out by Vanham (2020). Besides, these results are not representative and included women in majority and 6 plant-based diets that are typically lower in WFP (Harris et al., 2020). There was an 
$1 \mathrm{~A}$

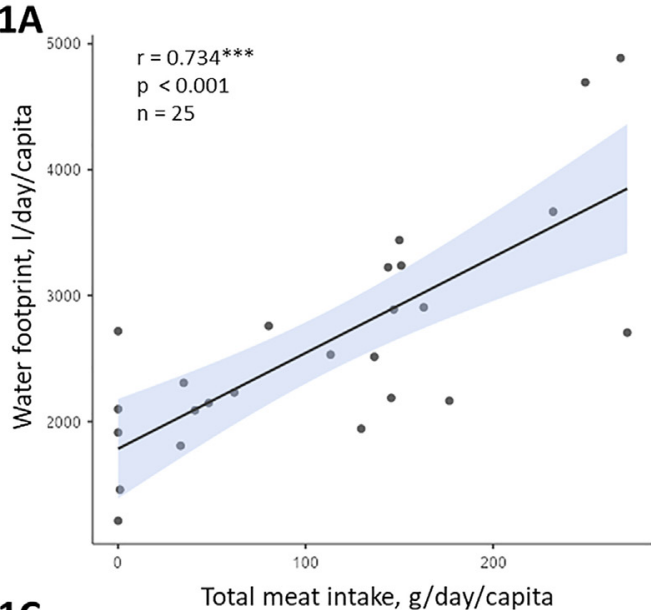

$1 C$

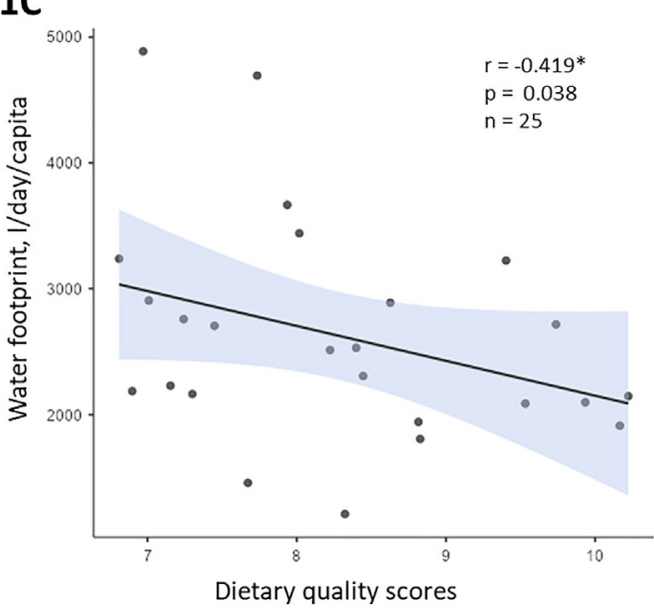

1B
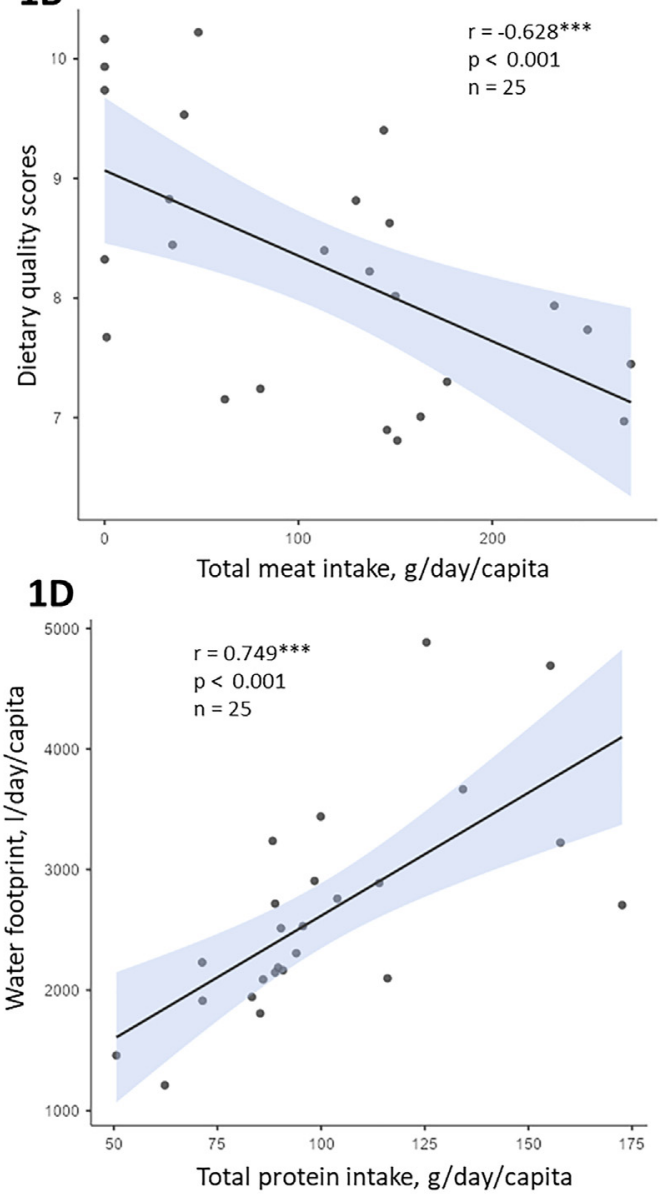

Fig. 1. A. Spearman's rank correlation between water footprint and total meat intake. B. Spearman's rank correlation between dietary quality scores and total meat intake. C. Spearman's rank correlation between water footprint and dietary quality scores. D. Spearman's rank correlation between water footprint and total protein intake

inverse correlation between the DQS and WFP (Fig. 1C) that suggests that the improvement of dietary quality would simultaneously decrease the dietary WFP. WFP was in a positive correlation with total meat intake (Fig. 1A), which is not surprising considering that meats usually have the greatest contribution to dietary WFP (Harris et al., 2020). Based on these results, it would be reasonable lowering meat intake, while increasing the intake of other animal- and plant-based protein sources. Furthermore, the DQS and total meat intake also showed an inverse correlation (Fig. 1B) that suggests that diets higher in meat content could be lower in dietary quality.

Table 1 shows no nutrients in $1 \mathrm{a}$ and 2 a groups, meaning that there was no negative significant correlation between water footprint and nutrient density values. Protein is classified in 
group $1 \mathrm{~b}$ as the only advantageous nutrient in a positive correlation with WFP (also see Fig. 1D). Group $2 \mathrm{~b}$ are the disadvantageous nutrients in positive correlation with WFP: energy $(r=0.690$, $P<0.001)$, sodium $(r=0.477, P=0.017)$ and saturated fatty acids $(r=0.668, P<0.001) .1 \mathrm{c}$ group contains dietary fibres, vitamin $\mathrm{C}$, calcium, and iron ( $\mathrm{mg} /$ day), while $2 \mathrm{c}$ consists of added sugars, from which none showed significant correlation with WFP $(P>0.05)$. The aim of the nutrient classification was to identify the integrative, environmental impact and dietary quality indicator nutrients. According to our results, the disadvantageous nutrients were mainly identifiable as indicator nutrients based on their significant, positive association with WFP. Therefore, these nutrients could be regarded as negative indicators for the aspects of both environmental impact and dietary quality, and lowering the intake of foods high in them could be recommended. Among the environmental pressures, the correlation between GHGE and energy density (Hendrie et al., 2016; van Dooren et al., 2017) or sodium and saturated fatty acids (van Dooren et al., 2017) in diets has been described in other studies. Protein should be emphasised as an indicator nutrient, however, it shows a controversal direction: it has been shown a positive, significant correlation with GHGE in other studies (Saarinen et al., 2017; van Dooren et al., 2017) and with WFP in this present one. On the other hand, it has also been classified as advantageous here and in other studies (Masset et al., 2014; Hallström et al., 2018) as well (Fig. 1D). Our research team has already detected this association regarding green water footprint and protein for the most consumed food products in Hungary (Tompa et al., 2020a). The quality and origin of protein play a key role here; based on these results, the modification in the quality of dietary protein could also be recommended by decreasing the intake of meat-based protein while increasing the intake of other animal- and plant-based protein.

\section{CONCLUSIONS}

In this present study, we aimed to develop a SN assessment tool that could be applied in the counseling practice of nutritionists and a methodology that would contribute to the basis of further studies. Our results suggest that a shift in the nutritional pattern could simultaneously direct to lower dietary WFP and better dietary quality, thus it could also contribute to the prevention of NCDs.

\section{ACKNOWLEDGEMENTS}

The study was supported by the Doctoral School of Food Sciences at the Hungarian University of Agriculture and Life Sciences. The project is supported by the European Union and co-financed by the European Social Fund (grant agreement no. EFOP-3.6.3- VEKOP-16-2017-00005).

\section{REFERENCES}

Barilla Center for Food and Nutrition (2015). Double pyramid 2015: Available at: https://www.barillacfn. com/m/publications/dp-2015-en.pdf (last accessed: 24 April 2020). 
EFSA (2017). Dietary reference values for nutrients summary report. EFSA Supporting Publications, 14(12): e15121E. https://doi.org/10.2903/sp.efsa.2017.e15121.

Fischer, C.G. and Garnett, T. (2016). Plates, pyramids and planets: developments in national healthy and sustainable dietary guidelines: a state of play assessment. FAO, Róma; FCRN, University of Oxford, Oxford. p. 71. Available at: http://www.fao.org/3/i5640e/I5640E.pdf (last accessed: 24 April 2020).

Hallström, E., Davis, J., Woodhouse, A., and Sonesson, U. (2018). Using dietary quality scores to assess sustainability of food products and human diets: a systematic review. Ecological Indicators, 93: 219-230.

Harris, F., Moss, C., Joy, E.J.M., Quinn, R., Scheelbeek, P.F.D., Dangour, A.D., and Green, R. (2020). The water footprint of diets: a global systematic review and meta-analysis. Advances in Nutrition, 11(2): 375-386.

Hendrie, G.A., Baird, D., Ridoutt, B., Hadjikakou, M., and Noakes, M. (2016). Overconsumption of energy and excessive discretionary food intake inflates dietary greenhouse gas emissions in Australia. Nutrients, 8(11): 690.

Hoekstra, A.Y. and Mekonnen, M.M. (2012). The water footprint of humanity. Proceedings of the National Academy of Sciences of the United States of America, 109(9): 3232-3237.

IHME (2019). GBD Database. Cause of death in both sexes at all ages and related risk factors in Hungary. Institute for Health Metrics and Evaluation IHME, University of Washington. Available from: https:// vizhub.healthdata.org/gbd-compare/ (last accessed: 01 March 2021).

Jamovi (2020). The jamovi project, jamovi. (Version 1.2) (Computer Software). Available at: https://www. jamovi.org. (last accessed: 01 March 2021).

Masset, G., Soler, L.G., Vieux, F., and Darmon, N. (2014). Identifying sustainable foods: the relationship between environmental impact, nutritional quality, and prices of foods representative of the French diet. Journal of the Academy of Nutrition and Dietetics, 114(6): 862-869.

May, J.O. and Looney, S.W. (2020). Sample size charts for spearman and kendall coefficients. Journal of Biometrics \& Biostatistics, 11(2): 5-11. https://doi.org/10.37421/jbmbs.2020.11.440.

Nagy, B, Nagy-Lőrincz, Z, Bakacs, M, Illés, É., Sarkadi Nagy, E., Erdei G., and Martos, É. (2017). Országos Táplálkozás és Tápláltsági Állapot Vizsgálat - OTÁP2014. IV. A magyar lakosság mikroelem-bevitele. (Hungarian Diet and Nutritional Status Survey - HDNSS 2014 II. Micro nutrient intake of the Hungarian population). Orvosi Hetilap, 158(21): 803-810.

R Core Team (2019). R: a language and environment for statistical computing. (Version 3.6) (Computer software). Available at: https://cran.r-project.org/. (last accessed: 01 March 2021).

Saarinen, M., Fogelholm, M., Tahvonen, R., and Kurppa, S. (2017). Taking nutrition into account within the life cycle assessment of food products. Journal of Cleaner Production, 149: 828-844.

Sarkadi Nagy, E., Bakacs, M., Illés, É., Nagy, B., Varga, A., Kis, O., Molnár, E., and Martos, É. (2017). Országos Táplálkozás és Tápláltsági Állapot Vizsgálat - OTÁP2014. II. A magyar lakosság energia- és makrotápanyag-bevitele. (Hungarian Diet and Nutritional Status Survey - HDNSS 2014 II. Energy and macro nutrient intake of the Hungarian population). Orvosi Hetilap, 158(15): 587-597.

Schreiberné Molnár, E., Nagy-Lőrincz, Z., Nagy, B., Bakacs, M., Kis, O., Sarkadi Nagy, E., and Martos, É. (2017). Országos Táplálkozás- és Tápláltsági Állapot Vizsgálat - OTÁP2014. V. A magyar lakosság vitaminbevitele (Hungarian diet and nutritional Status Survey - HDNSS 2014 II. Vitamin intake of the Hungarian population). Orvosi Hetilap, 158(33): 1302-1313.

Tompa, O., Kiss, A., and Lakner, Z. (2020a). Towards the sustainable food consumption in central Europe: stochastic relationship between water footprint and nutrition. Acta Alimentaria, 49: 86-92.

Tompa, O., Lakner, Z., Oláh, J., Popp, J., and Kiss, A. (2020b). Is the sustainable choice a healthy choice?water footprint consequence of changing dietary patterns. Nutrients, 12(9): 2578, 19 pages. 
van Dooren, C., Douma, A., Aiking, H., and Vellinga, P. (2017). Proposing a novel index reflecting both climate impact and nutritional impact of food products. Ecological Economics, 131: 389-398.

Vanham, D., Hoekstra, A.Y., and Bidoglio, G. (2013). Potential water saving through changes in European diets. Environment International, 61: 45-56.

Vanham, D., Leip, A., Galli, A., Kastner, T., Bruckner, M., Uwizeye, A., .. Hoekstra, A.Y. (2019). Environmental footprint family to address local to planetary sustainability and deliver on the SDGs. Science of the Total Environment, 693: 133642.

Vanham, D. (2020). Water resources for sustainable healthy diets: state of the art and outlook. Water, 12(11): 3224, 15 pages.

Open Access. This is an open-access article distributed under the terms of the Creative Commons Attribution 4.0 International License (https://creativecommons.org/licenses/by/4.0/), which permits unrestricted use, distribution, and reproduction in any medium, provided the original author and source are credited, a link to the CC License is provided, and changes - if any - are indicated. (SID_1) 